Check for updates

Cite this: RSC Adv., 2018, 8, 39865

Received 7th November 2018

Accepted 20th November 2018

DOI: $10.1039 / \mathrm{c} 8 \mathrm{ra09212e}$

rsc.li/rsc-advances

\section{Highly stereoselective spirocyclopropanation of various diazooxindoles with olefins catalyzed using Ru(II)-complex $\dagger$}

\author{
Masaya Tone, (D) a Yoko Nakagawa, (D) a Soda Chanthamath, ${ }^{a}$ Ikuhide Fujisawa, ${ }^{a}$ \\ Naofumi Nakayama, ${ }^{b}$ Hitoshi Goto, (D bc Kazutaka Shibatomi iD a and Seiji Iwasa*a
}

Optically active spirocyclopropyloxindole derivatives were efficiently synthesized from diazooxindoles and olefins in the presence of a Ru(॥)-Pheox catalyst. Among a series of Ru(॥)-Pheox catalysts, Ru(I)-Pheox 6e was determined to be the best catalyst for spirocyclopropanation reactions of diazooxindoles with various olefins in high yields (up to 98\%) with high diastereoselectivities (up to trans:cis $=>99: 1<$ ) and enantioselectivities (up to $99 \%$ ee). Furthermore, as the first catalytic asymmetric synthesis, anti-HIV active candidate $4 a$ and a bioactive compound of AMPK modulator $4 \mathrm{c}$ were easily synthesized from the corresponding diazooxindoles $1 \mathrm{i}$ and $1 \mathrm{~b}$, respectively, in high yields with high enantioselectivities (4a: $82 \%$ yield, 95\% ee, 4b: $99 \%$ yield, $93 \%$ ee).
The discovery of a new class of optically active cyclopropyl oxindoles, as shown below (Fig. 1), has stimulated intensive research interest in the development of biologically active new organic molecules in both academia and industry. ${ }^{1,2}$ These compounds were observed to be pharmacologically important substrates with potentially interesting biological activities-e.g., potent HIV inhibitors, ${ }^{3}$ and anti-cancer ${ }^{4}$ and inotrope agents. ${ }^{5}$ Furthermore, chiral spirocyclopropyl oxindoles are useful key intermediates for the ring-expansion reaction of spirocyclopropane rings via a concerted mechanism in the presence of a Lewis acid catalyst. ${ }^{6}$ As for the synthetic methodology, the transition-metal-catalyzed asymmetric cyclopropanation of diazooxindoles with olefins has been reported, which is one of the most direct and efficient pathways for the synthesis of chiral spirocyclopropyl oxindoles. After the first report by $\mathrm{Arai}^{7}$ and $\mathrm{Zhou}^{8}$ independently with Rh and $\mathrm{Hg}$ catalysts, Ding and co-workers reported the asymmetric cyclopropanation of diazooxindoles with alkenes using a $C_{2^{-}}$ symmetric spiroketal bisphosphine/Au(I) complex with good enantioselectivity. ${ }^{9}$ More recently, $\mathrm{Xu}$ and co-workers reported efficient dirhodium catalysts, which exhibited good to excellent enantioselectivity control with alkyl alkenes. ${ }^{10}$ Although effective catalysts and catalytic systems have been reported for the asymmetric cyclopropanation of diazooxindoles with olefins, the

${ }^{a}$ Department of Environmental and Life Sciences, Toyohashi University of Technology, Tempaku-cho, Toyohashi 441-8580, Japan. E-mail: iwasa@ens.tut.ac.jp

${ }^{b}$ CONFLEX Corporation, Shinagawa Center Building, 6F, 3-23-17 Takanawa Minatoku, Tokyo 108-0074, Japan

'Department of Computer Science and Engineering, Toyohashi University of Technology, Tempaku-cho, Toyohashi 441-8580, Japan

$\dagger$ Electronic supplementary information (ESI) available. CCDC 1874398. For ESI and crystallographic data in CIF or other electronic format see DOI: 10.1039/c8ra09212e development of effective and powerful methodologies to prepare the unique structural motif of a spirocyclopropyloxindole remains an active research area.

We reported a series of $\mathrm{Ru}$ (II) phenyloxazoline catalysts ( $\mathrm{Ru}$ (II)Pheox) in 2010, which effectively promoted the asymmetric intraand intermolecular carbene transfer reactions to olefins, $\mathrm{C}-\mathrm{H}, \mathrm{N}-$ $\mathrm{H}$, and $\mathrm{Si}-\mathrm{H}$ bonds in high yields with high enantioselectivities. ${ }^{11}$ Based on this study, we employed $\mathrm{Ru}(\mathrm{II})$-Pheox catalyst to synthesize a spirocyclopropanated oxindole from 5-bromo-3methylene-indolin-2-one and diazoacetate. ${ }^{12}$ However, in this study, the reactivities and stereoselectivities were reported with

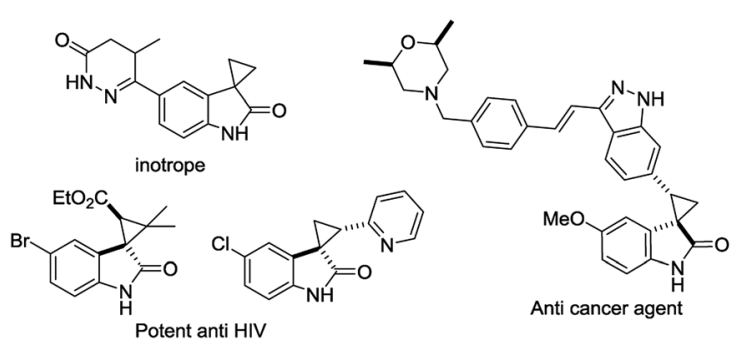

Fig. 1 Bioactive spirocyclopropyl oxindoles.

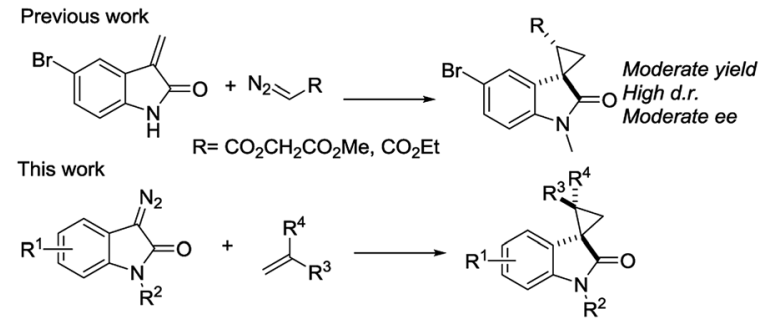

Fig. 2 Synthetic strategies of optically active spirocyclopropyl oxindole. 
Table 1 Screening of various catalysts ${ }^{a}$

6
6

${ }^{a}$ Reaction condition: catalyst $(1 \mathrm{~mol} \%)$ and styrene $2 \mathrm{a}$ (5.0 equiv., 1 mmol) were dissolved in $\mathrm{CH}_{2} \mathrm{Cl}_{2}(2.0 \mathrm{~mL})$, and diazooxindole $\mathbf{1 a}(0.2$ mmol) in $\mathrm{CH}_{2} \mathrm{Cl}_{2}(2 \mathrm{~mL})$ was added. ${ }^{b}$ Isolated yield. ${ }^{c}$ Determined by NMR. ${ }^{d}$ Determined by chiral HPLC analysis.

moderate, or even high, diastereoselectivities. To improve the yield and enantioselectivity, we initially used $\mathrm{Ru}(\mathrm{II})$-Pheox for the reaction of a diazooxindole of an olefin (Fig. 2).

First, we attempted a catalytic asymmetric cyclopropanation of diazooxindole 1a with styrene $\mathbf{2 a}$ catalyzed by authorized complexes such as $\mathbf{4}^{\mathbf{1 3}}$ and $\mathbf{5}^{\mathbf{1 4}}$ and a series of $\mathrm{Ru}$ (II)-Pheox catalysts. The results are summarized in Table 1 . The cyclopropanation with the commonly used catalysts $\mathbf{4}$ and $\mathbf{5}$ proceeded with low stereoselectivities (Table 1, entries 1 and 2). A series of Ru(II)-Pheox catalysts was also tested for the spirocyclopropanation reaction.
The reaction of diazooxindole 1a proceeded smoothly at room temperature to afford the desired cyclopropane product 3a in high yield with moderate enantioselectivity (Table 1, entry 3 ).

To improve the enantioselectivity, the $\mathrm{Ru}(\mathrm{II})-\mathrm{Ph}$ eox $6 \mathbf{6}$ catalyst was modified in terms of electron density on the aromatic ring connecting with $\mathrm{Ru}(\mathrm{II})$ and a chiral environment (6b-e). Catalyst screening of various Ru(II)-Pheox 6 catalysts is shown in Table 1 (entries 3-7). Consequently, we determined that the reactivity- and enantioselectivity-related electronic effect on the aromatic ring was slightly effective and increased the enantioselectivity to $61 \%$ ee with the use of $\mathrm{Ru}(\mathrm{II})$-Pheox $\mathbf{6 d}$ having an electron-withdrawing group such as $\mathrm{NO}_{2}$ (Table 1, entry 6). However, a much more effective catalyst, $\mathrm{Ru}(\mathrm{II})$-Pheox $\mathbf{6} \mathrm{e}^{\mathbf{1 5}}$ having an indane-derived chiral environment, was observed to have higher activity and enantioselectivity than the other Ru(II)Pheox 6a catalysts, resulting in the corresponding product in high yield (98\%) with excellent diastereoselectivity (94:6) and high enantioselectivity ( $92 \%$ ee) (Table 1 , entry 7 ).

To improve the diastereoselectivity and enantioselectivity of this catalytic system further, we examined the cyclopropanation in various solvents (Table 2, entries 1-5). For all tested solvents, spirocyclopropanation proceeded smoothly in high yield but with differing diastereoselectivities and enantioselectivities. Toluene led to an improvement of trans-selectivity (trans/cis = 97:3) and enantioselectivity ( $94 \%$ ee). Toluene and dichloromethane were observed to be suitable solvents for the spirocyclopropanation of diazooxindole and olefins catalyzed by $\mathrm{Ru}(\mathrm{II})$-Pheox 6e. The effect of temperature on the reaction was also investigated (Table 2, entries 6-9), showing that enantioselectivity could be improved to $96 \%$ ee at a temperature of $0{ }^{\circ} \mathrm{C}$ (Table 2, entry 7). As such, $0{ }^{\circ} \mathrm{C}$ was determined to be the optimal temperature for this catalytic system.

Subsequently, we briefly examined the effect of $\mathrm{N}$-substituted group under these optimized conditions. The result is summarized in Table 3. N-Alkyl diazooxindoles were subjected to these conditions with 2a. N-Benzyl group had some effects on the yield and resulted in the highest stereoselectivity in terms of both

Table 2 Optimization of reaction conditions ${ }^{a}$

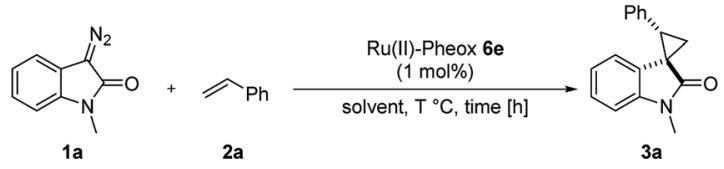

\begin{tabular}{|c|c|c|c|c|c|c|}
\hline Entry & Solvent & $T\left[{ }^{\circ} \mathrm{C}\right]$ & Time $[\mathrm{h}]$ & Yield $^{b}[\%]$ & trans $/$ cis $^{c}$ & $\mathrm{ee}^{d}[\%]$ \\
\hline 1 & THF & $\mathrm{rt}$ & 7 & 77 & $96: 4$ & 94 \\
\hline 2 & $\mathrm{CH}_{2} \mathrm{Cl}_{2}$ & $\mathrm{rt}$ & 6 & 91 & $94: 6$ & 92 \\
\hline 4 & $\mathrm{CH}_{3} \mathrm{CN}$ & $\mathrm{rt}$ & 42 & 53 & $77: 23$ & 76 \\
\hline $5^{e}$ & Toluene : $\mathrm{CH}_{2} \mathrm{Cl}_{2}$ & $\mathrm{rt}$ & 6 & 97 & $91: 9$ & 95 \\
\hline 6 & Toluene & $\mathrm{rt}$ & 24 & 95 & $97: 3$ & 94 \\
\hline 9 & Toluene & -20 & 24 & 92 & $92: 8$ & 91 \\
\hline
\end{tabular}

${ }^{a}$ Reaction condition: catalyst $(1 \mathrm{~mol} \%)$ and styrene $2 \mathrm{a}(5.0$ equiv., $1 \mathrm{mmol})$ were dissolved in $\mathrm{CH}_{2} \mathrm{Cl}_{2}(2.0 \mathrm{~mL})$, and diazooxindole $1 \mathrm{a}(0.2 \mathrm{mmol})$ in

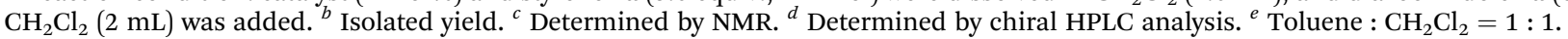


Table 3 Substituent effect on nitrogen of diazooxindole $1 \mathrm{a}-1 \mathrm{~d}^{a}$
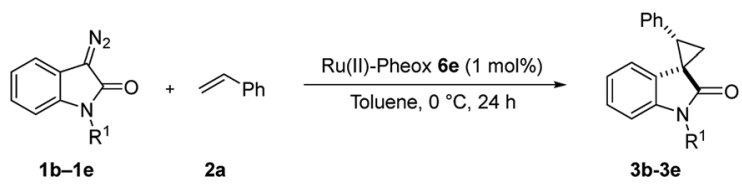

\begin{tabular}{llllll}
\hline Entry & $\mathrm{R}^{1}$ & Product & Yield $^{b}[\%]$ & ${\text { trans } / \text { cis }^{c}}$ & $\mathrm{ee}^{d}[\%]$ \\
\hline $1^{e}$ & $\mathrm{H}$ & 3b & 98 & $93: 7$ & 92 \\
2 & $\mathrm{Et}$ & $\mathbf{3 c}$ & 94 & $97: 3$ & 97 \\
3 & $\mathrm{iPr}$ & 3d & 86 & $96: 4$ & 95 \\
4 & $\mathrm{Bn}$ & 3e & 97 & $>99: 1<$ & 98
\end{tabular}

${ }^{a}$ Reaction condition: catalyst $(1 \mathrm{~mol} \%)$ and styrene 2 (5.0 equiv., 1 mmol) were dissolved in $\mathrm{CH}_{2} \mathrm{Cl}_{2}(2.0 \mathrm{~mL})$, and diazooxindole $1(0.2$ mmol) in $\mathrm{CH}_{2} \mathrm{Cl}_{2}(2 \mathrm{~mL})$ was added. ${ }^{b}$ Isolated yield. ${ }^{c}$ Determined by NMR. ${ }^{d}$ Determined by chiral HPLC analysis. ${ }^{e} \mathrm{CH}_{2} \mathrm{Cl}_{2}$ was used as the solvent.

diastereoselectivity and enantioselectivity even far from the reactive site (Table 3, entry 4). When i-Pr group was used to substitute nitrogen, the yield was slightly decreased (Table 3, entry 3).

We subsequently explored the scope and generality of the catalytic system (Table 4). Various vinyl arenes were reacted with diazooxindole 1a in the presence of $\mathrm{Ru}(\mathrm{II})-\mathrm{Pheox} 6 \mathbf{6}$. Most of the vinyl arenes provided the corresponding spirocyclopropanation products in high yields (up to $98 \%$ yields) with high diastereoselectivities and enantioselectivities $93-99 \%$ ee (Table 4, entries 1-11). Germinal disubstituted olefin, $\alpha$-methylstyrene $2 \mathbf{g}$, also provided the product $3 \mathbf{k}$ in good yield with excellent diastereoselectivity and enantioselectivity (97\% ee) (Table 4, entry 7). However, low enantioselectivity of $24 \%$ ee was observed in the case of cyclopropanation of $4-\mathrm{Me}_{2} \mathrm{~N}$-substituted-styrene, which might be unstable during the purification following cyclopropane ring-opening reaction assisted by an electrondonating group (Table 4 , entry 12 ).

Furthermore, various oxindoles examined under similar conditions resulted in high yields and stereoselectivities, except 5-Br group (Table 4, entries 13-15). The cyclopropanation of aliphatic alkenes such as 1-hexane, multi-substituted olefins, inner alkene derivatives and $\alpha, \beta$-unsaturated carbonyl compounds was also examined; however, no cyclopropane product was observed owing to rapid dimerization from the diazo compound.

Furthermore, hetero-atom-substituted olefins were examined for spirocyclopropanation reactions. The results are summarized in Table 5. Various N-alkyl diazooxindoles were subjected to these conditions with $\mathbf{2 a}$, and all the tested diazooxindoles provided the cyclopropane product in good yields with high diastereoselectivity and enantioselectivity.

When the substrate has low solubility in toluene, a mixed solvent system such as $\mathrm{CH}_{2} \mathrm{Cl}_{2}$ : toluene $=1: 1$ is efficient to improve the reactivity without decreasing the stereoselectivity (Table 5, entries 1, 2, and 4). Proton nuclear magnetic resonance (H-NMR) analysis suggested the quantitative yield for the spirocyclopropanation reaction of vinyl phthalimide 20 although the isolated yield was $37 \%$. The product $3 \mathbf{w}$ from vinyl phthalimide was unstable during the purification through column chromatography on both silica gel and alumina (Table 5, entry 4 ).

Furthermore, we investigated the estimation of the transition state related to the reaction mechanism using

Table 4 Spirocyclopropanation of diazooxindole 1 a with styrene derivatives $2^{a}$

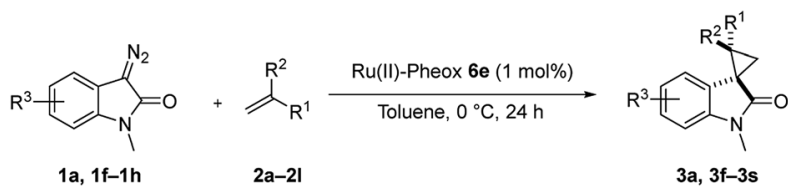

\begin{tabular}{|c|c|c|c|c|c|c|c|}
\hline Entry & $\mathrm{R}^{1}$ & $\mathrm{R}^{2}$ & $\mathrm{R}^{3}$ & Product & Yield $^{b}[\%]$ & trans $/$ cis $^{c}$ & $\mathrm{ee}^{d}[\%]$ \\
\hline 1 & $\mathrm{Ph}$ & $\mathrm{H}$ & $\mathrm{H}$ & $3 a$ & 94 & $94: 6$ & 96 \\
\hline 2 & $o-\mathrm{MeC}_{6} \mathrm{H}_{4}$ & $\mathrm{H}$ & $\mathrm{H}$ & $3 f$ & 92 & $92: 8$ & 95 \\
\hline 4 & $p-\mathrm{MeC}_{6} \mathrm{H}_{4}$ & $\mathrm{H}$ & $\mathrm{H}$ & $3 \mathrm{~h}$ & 96 & $>99: 1<$ & 96 \\
\hline 5 & $p$ - $\mathrm{tBuC}_{6} \mathrm{H}_{4}$ & $\mathrm{H}$ & $\mathrm{H}$ & $3 \mathbf{i}$ & 97 & $>99: 1<$ & 95 \\
\hline $6^{e}$ & $\mathrm{~Np}$ & $\mathrm{H}$ & $\mathrm{H}$ & $3 \mathbf{j}$ & 83 & $>99: 1<$ & 96 \\
\hline 9 & $p-\mathrm{BrC}_{6} \mathrm{H}_{4}$ & $\mathrm{H}$ & $\mathrm{H}$ & $3 m$ & 98 & $96: 4$ & 94 \\
\hline 10 & $p-\mathrm{ClC}_{6} \mathrm{H}_{4}$ & $\mathrm{H}$ & $\mathrm{H}$ & $3 n$ & 98 & $96: 4$ & 93 \\
\hline 11 & $p-\mathrm{OMeC}_{6} \mathrm{H}_{4}$ & $\mathrm{H}$ & $\mathrm{H}$ & 30 & 79 & $>99: 1<$ & 97 \\
\hline 12 & $p-\mathrm{NMe}_{2} \mathrm{C}_{6} \mathrm{H}_{4}$ & $\mathrm{H}$ & $\mathrm{H}$ & $3 p$ & 74 & $>99: 1<$ & 24 \\
\hline 13 & $\mathrm{Ph}$ & $\mathrm{H}$ & $5-\mathrm{Br}$ & $3 q$ & 93 & $89: 11$ & 87 \\
\hline 14 & $\mathrm{Ph}$ & $\mathrm{H}$ & 6-Cl & $3 r$ & 98 & $96: 4$ & 99 \\
\hline
\end{tabular}

${ }^{a}$ Reaction condition: catalyst $(1 \mathrm{~mol} \%)$ and styrene 2 (5.0 equiv., $\left.1 \mathrm{mmol}\right)$ were dissolved in $\mathrm{CH}_{2} \mathrm{Cl}_{2}(2.0 \mathrm{~mL})$, and diazooxindole 1 (0.2 mmol) in $\mathrm{CH}_{2} \mathrm{Cl}_{2}(2 \mathrm{~mL})$ was added. ${ }^{b}$ Isolated yield. ${ }^{c}$ Determined by NMR. ${ }^{d}$ Determined by chiral HPLC analysis. ${ }^{e}$ Toluene $: \mathrm{CH}_{2} \mathrm{Cl}_{2}$ was used as the solvent.

${ }^{f}$ Slow addition for $4 \mathrm{~h}$, and stirring for $20 \mathrm{~h}$. 
Table 5 Cyclopropanation of diazooxindole 1a with vinyl ester and vinyl amines ${ }^{a}$

Entry

${ }^{a}$ Reaction condition: catalyst $(1 \mathrm{~mol} \%)$ and styrene 2 (5.0 equiv., 1 mmol) were dissolved in $\mathrm{CH}_{2} \mathrm{Cl}_{2}(2.0 \mathrm{~mL})$, and diazooxindole $1(0.2$ $\mathrm{mmol})$ in $\mathrm{CH}_{2} \mathrm{Cl}_{2}(2 \mathrm{~mL})$ was added. ${ }^{b}$ Isolated yield. ${ }^{c}$ Determined by NMR. ${ }^{d}$ Determined by chiral HPLC analysis. ${ }^{e}$ Toluene : $\mathrm{CH}_{2} \mathrm{Cl}_{2}$ was used as the solvent. ${ }^{f}$ Slow addition for $4 \mathrm{~h}$, and stirring for $20 \mathrm{~h}$. g $98 \%$ conversion.

computational chemical analysis for the metal-carbene complex derived from diazooxindole and $\mathrm{Ru}(\mathrm{II})$-Pheox catalyst (Table S1, Fig. 3 and S1-S3†). ${ }^{17-19}$ The computational chemical analysis shows the Ru-oxindole carbene complex, which suggests that $\pi-\pi$ interaction between oxindole and the indane aromatic ring controls the chiral environment to induce high enantioselectivity. Thus, an olefin may approach from only one side to provide high stereoselectivity as shown in Fig. 3. The absolute stereochemistry was determined using X-ray analysis (Scheme 1).

To demonstrate the utility of our direct enantioselective cyclopropyloxindole synthesis, we demonstrated the first catalytic asymmetric synthesis of bioactive compounds such as antiHIV activity candidate $\mathbf{4 a}$ and AMPK modulator $\mathbf{4 c}$ from diazooxindoles $\mathbf{1 i}$ and $\mathbf{1 b}$, respectively. Both spirocyclopropanations proceeded smoothly, resulting in high yield with high enantioselectivity (4a: $82 \%$ yield, $95 \%$ ee, 4 b: $99 \%$ yield, $93 \%$ ee as it is methyl ester). ${ }^{2 e, 16}$

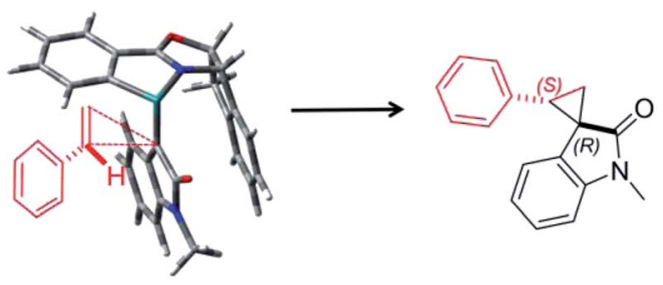

Fig. 3 Plausible transition state of spirocyclopropanation.

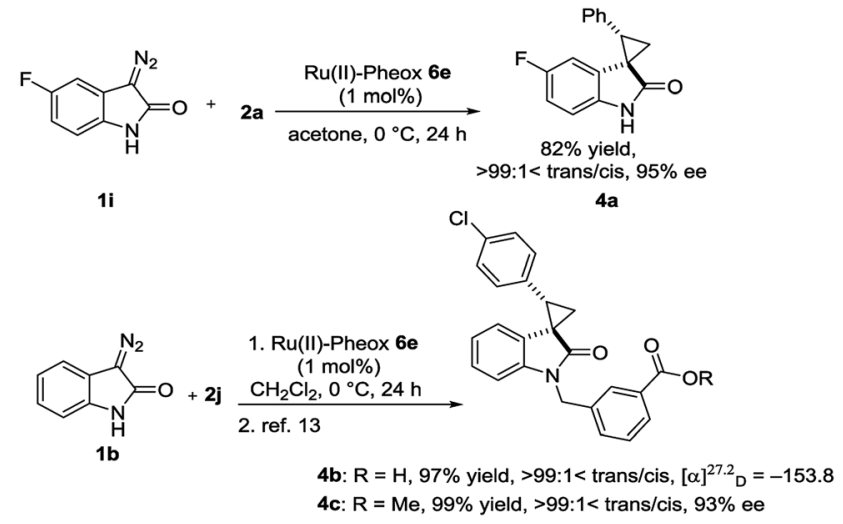

Scheme 1 Synthesis of bioactive compounds.

In summary, the catalytic asymmetric cyclopropanation reaction of diazooxindoles and olefins by a series of $\mathrm{Ru}(\mathrm{II})$-Pheox catalysts is very effective for the synthesis of optically active spirocyclopropyloxindole derivatives. The stereoselectivity is good to excellent in most cases and optically active spirocyclopropyloxindole derivatives can be synthesized under a mild reaction condition in a short step. Furthermore, this strategy could be applied for the first synthesis of optically active bioactive compounds such as anti-HIV candidates and an AMPK modulator.

\section{Conflicts of interest}

There are no conflicts to declare.

\section{Acknowledgements}

S. I. thank Ikeda Bussan Co. Ltd. for partial financial support for this study.

\section{Notes and references}

1 (a) C. Marit and E. M. Carreira, J. Am. Chem. Soc., 2005, 127, 11505; (b) N. Ye, H. Chen, E. A. Wold, P.-Y. Shi and J. Zhou, ACS Infect. Dis., 2016, 2, 382.

2 (a) Z.-Y. Cao, Y.-H. Wang, X.-P. Zeng and J. Zhou, Tetrahedron Lett., 2014, 55, 2571; (b) S. Muthusamy and R. Ramkumar, Tetrahedron Lett., 2014, 55, 6389; (c) F. Pesciaioli, P. Righi, A. Mazzanti, G. Bartoli and G. Bencivenni, Chem.-Eur. J., 2011, 17, 2842; (d) A. Noole, M. Ošeka, T. Pehk, M. Öeren, I. Järving, M. R. J. Elsegood, A. V. Malkov, M. Lopp and T. Kanger, Adv. Synth. Catal., 2013, 355, 829; (e) M. Palomba, L. Rossi, L. Sancineto, E. Tramontano, A. Corona, L. Bagnoli, C. Santi, C. Pannecouque, O. Tabarrini and F. Marini, Org. Biomol. Chem., 2016, 14, 2015; $(f)$ C. L. Ladd, D. S. Roman and A. B. Charette, Org. Lett., 2013, 15, 1350; $(g)$ S. Muthusamy, D. Azhagan, B. Gnanaprakasam and E. Suresh, Tetrahedron Lett., 2010, 51, 5662; (h) G.-J. Mei and F. Shi, Chem. Commun., 2018, 54, 6607; (i) Z.-Y. Cao, F. Zhou and J. Zhou, Acc. Chem. Res., 2018, 51, 1443; (j) N. Huang, L. Zou and Y. Peng, Org. Lett., 2017, 19, 5806. 
3 (a) T. Jiang, K. L. Kuhen, K. Wolff, H. Yin, K. Bieza, J. Caldwell, B. Bursulaya, T. Y.-H. Wu and Y. He, Bioorg. Med. Chem. Lett., 2006, 16, 2105; (b) T. Jiang, K. L. Kuhen, K. Wolff, H. Yin, K. Bieza, J. Caldwell, B. Bursulaya, T. Tuntland, K. Zhang, D. Karanewsky and Y. He, Bioorg. Med. Chem. Lett., 2006, 16, 2109.

4 (a) S.-W. Li, Y. Liu, P. B. Sampson, N. K. Patel, B. T. Forrest, L. Edwards, R. Laufer, M. Feher, F. Ban, D. E. Awrey, R. Hodgson, I. Beletskaya, G. Mao, J. M. Mason, X. Wei, X. Luo, R. Kiarash, E. Green, T. W. Mak, G. Pan and H. W. Pauls, Bioorg. Med. Chem. Lett., 2016, 26, 4625; (b) J. M. Mason, D. C.-C. Lin, X. Wei, Y. Che, Y. Yao, R. Kiarash, D. W. Cescon, G. C. Fletcher, D. E. Awrey, M. R. Bray, G. Pan and T. W. Mak, Cancer Cell, 2014, 26, 163. 5 D. W. Robertson, J. H. Krushinski, G. D. Pollock, H. Wilson, R. F. Kauffman and J. S. Hayes, J. Med. Chem., 1987, 30, 824. 6 P.-W. Xu, J.-K. Liu, L. Shen, Z.-Y. Cao, X.-L. Zhao, J. Yan and J. Zhou, Nat. Commun., 2017, 8, 1619.

7 (a) A. Awata and T. Arai, Synlett, 2013, 24, 29; (b) Y.-S. Xue, Y.-P. Cai and Z.-X. Chen, RCS Adv, 2015, 5, 57781.

8 Z.-Y. Cao, F. Zhou, Y.-H. Yu and J. Zhou, Org. Lett., 2013, 15, 42.

9 Z.-Y. Cao, X. Wang, C. Tan, X.-L. Zhao, J. Zhou and K. Ding, J. Am. Chem. Soc., 2013, 135, 8197.

10 Y. Chi, L. Qiu and X. Xu, Org. Biomol. Chem., 2016, 14, 10357. 11 (a) A. M. Abu-Elfotoh, K. Phemkeona, K. Shibatomi and S. Iwasa, Angew. Chem., Int. Ed., 2010, 49, 8439; (b) S. Chanthamath, K. Phomkeona, K. Shibatomi and S. Iwasa, Chem. Commun., 2012, 48, 7750; (c) A. M. AbuElfotoh, D. P. T. Nguyen, S. Chanthamath, K. Phomkeona, K. Shibatomi and S. Iwasa, Adv. Synth. Catal., 2012, 354, 3435; (d) S. Chanthamath, D. T. Nguyen, K. Shibatomi and S. Iwasa, Org. Lett., 2013, 15, 772; (e) S. Chanthamath, S. Ozaki, K. Shibatomi and S. Iwasa, Org. Lett., 2014, 16, 3012; (f) S. Chanthamath, H. W. Chua, S. Kimura, S. Shibatomi and S. Iwasa, Org. Lett., 2014, 16, 3408; $(g)$ Y. Nakagawa, S. Chanthamath, K. Shibatomi and S. Iwasa, Org. Lett., 2015, 17, 2792; (h) S. Chanthamath, H. S. A. Mandour, T. T. M. Thu, K. Shibatomi and S. Iwasa, Chem. Commun., 2016, 52, 7814; (i) S. Chanthamath and
S. Iwasa, Acc. Chem. Res., 2016, 49, 2080; (j) H. S. A. Mandour, S. Chanthamath, K. Shibatomi and S. Iwasa, Adv. Synth. Catal., 2017, 359, 1742.

12 S. Chanthamath, S. Takaki, K. Shibatomi and S. Iwasa, Angew. Chem., Int. Ed., 2013, 52, 5818.

13 T. Goto, K. Takeda, M. Anada, K. Ando and S. Hashimoto, Tetrahedron Lett., 2011, 52, 4200.

14 (a) W. Kirmse, Angew. Chem., Int. Ed., 2003, 42, 1088; (b) H. A. McManus and P. J. Guiry, Chem. Rev., 2004, 104, 4151; (c) G. Desimono, G. Fuita and K. A. Jørgensen, Chem. Rev., 2006, 106, 3561.

15 K.-X. Huang, M.-S. Xie, G.-F. Zhao, G.-R. Qu and H.-M. Guo, Adv. Synth. Catal., 2016, 358, 3627.

16 L. Chen, M. Huang, L. Feng, Y. He and H. Yun, WO2011/ 069298 A1, 2011.

17 (a) H. Goto and E. Osawa, J. Am. Chem. Soc., 1989, 111, 8950; (b) H. Goto and E. Osawa, J. Chem. Soc. Perkin Trans. 2, 1993, 187.

18 H. Goto, S. Obata, N. Nakayama and K. Ohta, CONFLEX 8, CONFLEX Corporation, Tokyo, Japan, 2017.

19 M. J. Frisch, G. W. Trucks, H. B. Schlegel, G. E. Scuseria, M. A. Robb, J. R. Cheeseman, G. Scalmani, V. Barone, G. A. Petersson, H. Nakatsuji, X. Li, M. Caricato, A. V. Marenich, J. Bloino, B. G. Janesko, R. Gomperts, B. Mennucci, H. P. Hratchian, J. V. Ortiz, A. F. Izmaylov, J. L. Sonnenberg, D. Williams-Young, F. Ding, F. Lipparini, F. Egidi, J. Goings, B. Peng, A. Petrone, T. Henderson, D. Ranasinghe, V. G. Zakrzewski, J. Gao, N. Rega, G. Zheng, W. Liang, M. Hada, M. Ehara, K. Toyota, R. Fukuda, J. Hasegawa, M. Ishida, T. Nakajima, Y. Honda, O. Kitao, H. Nakai, T. Vreven, K. Throssell, J. A. Montgomery Jr, J. E. Peralta, F. Ogliaro, M. J. Bearpark, J. J. Heyd, E. N. Brothers, K. N. Kudin, V. N. Staroverov, T. A. Keith, R. Kobayashi, J. Normand, K. Raghavachari, A. P. Rendell, J. C. Burant, S. S. Iyengar, J. Tomasi, M. Cossi, J. M. Millam, M. Klene, C. Adamo, R. Cammi, J. W. Ochterski, R. L. Martin, K. Morokuma, O. Farkas, J. B. Foresman and D. J. Fox, Gaussian 16, Revision A.03, Gaussian, Inc., Wallingford CT, 2016. 